\title{
MIKROSIECI JAKO INNOWACYJNY KOMPONENT DYWERSYFIKACJI RYNKU ENERGETYCZNEGO W POLSCE
}

DOI: $10.33141 /$ po.2019.09.03

\author{
Sylwia Sysko-Romańczuk, Grzegorz Kluj
}

\section{Wprowadzenie}

D ostęp w dziedzinie innowacji, jakimi są odnawialne źródła energii (OZE, ang., Renewable Energy Sources - RES), oraz w technologiach im towarzyszących, jak magazynowanie energii, sprawił, że dziś możemy mówić o realniej alternatywie dla dotychczasowych rozwiązań stosowanych dla zabezpieczenia energetycznego gospodarki i kraju. Na całym świecie OZE stają się opcją przejścia na bezpieczne, opłacalne i ekologiczne źródła energii. Poprzez swoje rozproszenie $\mathrm{z}$ jednej strony poprawiają bezpieczeństwo energetyczne, a $\mathrm{z}$ drugiej tworzą lokalną wartość dodaną. Warto dodać, że przeciwdziałają niekorzystnym globalnym i lokalnym zmianom klimatycznym. Niniejszy artykuł wpisuje się w aktualną dyskusję dotyczącą kształtowania polityki publicznej, jaką jest bezpieczeństwo energetyczne kraju (Pylak i in., 2017, s. 22-27). Podobnie, jak w przypadku polityk rynkowych, polityki publiczne w zakresie implementacji rozwiązań i technologii innowacyjnych powinny być stale analizowane i aktualizowane pod kątem możliwości realizowania dzięki nim postawionych celów (Hildermeier i in., 2019, s. 43).

$\mathrm{W}$ artykule podjęto dyskusję nad procesową koncepcją funkcjonowania organizacji mikrosieci - innowacyjnego i komplementarnego komponentu rynku energetycznego w Polsce zapewniającego dywersyfikację dostaw energii. Dokonano przeglądu różnych podejść i opinii naukowców, ekspertów i użytkowników branżowych oraz oceny dotychczasowych przykładów rozwiązań łączących technologie konwencjonalne z OZE. Rezultatem tej analizy była pozytywna weryfikacja hipotezy badawczej, że identyfikacja i opis procesów zapewniających sterowalną ciągłość działania mikrosieci jest kluczowym czynnikiem sukcesu zapewniającym prawidłową ich implementację rynkową. Zasadniczym kryterium identyfikacji i opisu kluczowych procesów mikrosieci jest zapewnienie jej sterowalnej ciągłości działania. Jest to taka cecha procesów, która zapewnia na linii źródło energii - odbiór - magazynowanie - dystrybucja - odbiorca, sterowany przez Operatora, stabilny przepływ mocy, także w przypadku dużej liczby źródeł zasilania usytuowanych w pobliżu punktów odbiorów oraz skoordynowaną pracę wyspową różnych źródeł energii (wiatr, słońce) i urządzeń odbiorczych. Celem naukowym artykułu jest identyfikacja kluczowych procesów w organizacji mikrosieci w oparciu o wypracowaną jej koncepcję procesową. Do realizowania tak przyjętego celu zastosowano triangulację badawczą. Wykorzystano analizę piśmiennictwa w zakresie zarządzania rozwojem techniki oraz raportów badawczych w zakresie dobrych praktyk wdrożeniowych organizacji mikrosieci w Europie i w USA. Przeprowadzono wywiady z ekspertami, analitykami i użytkownikami rynku energetycznego w celu weryfikacji przyjętej hipotezy. Zebrany materiał uzupełniono o wiedzę ekspercką autorów.

Głównymi czynnikami, które decydują o rozwoju OZE, są: spadające koszty produkcji OZE i magazynów energii; rosnące stawki opłat za energię elektryczną oraz coraz bardziej zdecydowane wysiłki polityczne zmierzające do ograniczania emisji gazów cieplarnianych przy jednoczesnej promocji rozproszonych zasobów energii (Ryan i in., 2017, s. 47-61). Ponadto rozwój inicjatyw lokalnych opartych o nowe podmioty wykorzystujące rozproszone, odnawialne źródła energii (OZE) i technologie im towarzyszące podnosi dyskusję na temat nieuchronnej zmiany $\mathrm{w}$ funkcjonowaniu rynku energii, w tym także w sposobie dystrybucji energii elektrycznej.

\section{Równoważenie popytu i podaży na energię elektryczną z rozproszonych zasobów energii i źródeł konwencjonalnych - założenia badawcze}

$M$ ożliwość wykorzystania lokalnych zasobów energii do podtrzymania zasilania odbiorów jest korzystną cechą sieci z generacją rozproszoną. Od lat 90 . w polskiej literaturze przedmiotu opisywano już różne propozycje decentralizacji rynku energetycznego (Krysta i in., 2002, s. 21-26; Kłysz, 1999, s. 16-20). Współczesne rozwiązanie nadal generuje duże problemy techniczno-organizacyjne powiązane w szczególności z potrzebą eliminacji ryzyk wynikających z niekontrolowanej pracy wyspowej, w tym komplikacje związane $\mathrm{z}$ niesynchronicznym, ponownym połączeniem z siecią dystrybucyjną (Wasiak i in., 2013). Obecne zapisy IRiESD ściśle regulują zasady pracy w układzie wyspowym ${ }^{1}$.

Równoważenie popytu ze zmienną podażą OZE za pomocą procesowej organizacji mikrosieci jest dużym wyzwaniem nie tylko dla teorii, ale i praktyki nauk o zarządzaniu. Wyniki prac badawczych prezentowanych w niniejszej publikacji oparto na analizie następujących źródeł wiedzy: (1) najnowszych publikacjach w czasopismach naukowych i branżowych związanych $\mathrm{z}$ technologiami 
OZE i ich wpływem na istniejącą infrastrukturę energetyczną, (2) przeglądzie dostępnych praktyk rynkowych $\mathrm{w}$ zakresie planowanych i realizowanych inwestycji dywersyfikujących rynek energetyczny w krajach europejskich-analiza dostępnych na stronach internetowych dokumentów - dla odbiorców, sprzedawców i innych podmiotów (w tym IRiESD ${ }^{2}$ ) rynku energii elektrycznej, jakimi są np. Operatorzy Systemów Dystrybucyjnych (OSD), (3) zasadach projektowania i utrzymania sieci elektroenergetycznej oraz organizacji prac na sieci elektroenergetycznej (wywiady z ekspertami branżowymi), (4) wyzwaniach związanych $z$ technologiami innowacyjnymi w zakresie ich działania, kontroli i ochrony (wywiady z ekspertami naukowymi).

Artykuł podejmuje nowe, nieporuszane dotychczas zagadnienia dotyczące tematyki mikrosieci i ma charakter interdyscyplinarny. Obejmuje swoim zakresem zarówno kwestie techniczne, jak i zarządcze, co, zdaniem autorów, stanowi jego atut.

\section{Mikrosieci jako nowa forma organizacji rozproszonych odnawialnych zasobów energii}

M ikrosieć ${ }^{3}$ to mała sieć energetyczna $z$ generacją rozproszoną, obejmująca urządzenia magazynujące energię i kontrolowalne obciążenia (Mumtaz, Bayram, 2016, s. 94-100). Ostatnia dekada charakteryzuje się szczególnie intensywnym rozwojem niskoemisyjnych i odnawialnych technologii źródeł energii, takich jak: skojarzone wytwarzanie ciepła i energii elektrycznej (CHP - opalanie gazem), instalacje PV, kolektory słoneczne, turbiny wiatrowe, ogniwa paliwowe, elektrownie wodne małych mocy, pompy ciepła i inne. Równocześnie wyraźnie dostrzegalny jest rozwój technologii magazynowania energii w postaci różnego typu zasobników, jak np. bateryjnych (akumulatory), kinetycznych FES (ang. Flywheel Energy Storage), nadprzewodnikowych, superkondensatorów, układów CAES (ang. Compressed Air Energy Storage) i innych. Razem technologie te wraz z usługami towarzyszącymi stanowią rozproszone zasoby energii (ang. Distributed Energy Resources - DER). Mikrosieć można zatem utworzyć poprzez odpowiednie zorganizowanie wymienionych elementów i usług występujących na ograniczonym terytorialnie obszarze geograficznym. Może ona łączyć się i odłączać od sieci dystrybucyjnej, do której jest przyłączona, aby umożliwić jej działanie zarówno w trybie synchronizacji, jak i wyspowym (Hirsch i in., 2018, s. 402-411). Mikrosieci mogą także integrować w sobie sieci ciepłownicze, gazowe i ciepłej wody użytkowej oraz związane z nimi innowacyjne usługi, jak DSR, Agregator i inne (Study on the effective ..., 2015, s. 118-128). Eksperci twierdzą, że rozwiązanie to oferuje szereg korzyści, wśród których najczęściej wymienia się: większą wydajność energetyczną i odporność na awarie zasilania z sieci zasilającej, redukcję kosztów, redukcję strat w przesyle i dystrybucji energii, poprawę bezpieczeństwa pracy sieci, redukcję emisji $\mathrm{CO}_{2}$ i korzyści środowiskowe.

\section{Funkcjonowanie mikrosieci a funkcjonowanie konwencjonalnej infrastruktury energetycznej}

W efekcie rozwoju generacji rozproszonej dochodzi do (Parol, 2013, s. 12) powstawania dużej liczby miejsc dostarczających energię, dwukierunkowych przepływów mocy oraz potrzeby instalowania urządzeń sterujących przepływani mocy. Instalowanie wymienionych wyżej urządzeń na coraz większą skalę sprzyja organizowaniu się ich właścicieli w wydzielone organizacyjnie byty i w dłuższym okresie będzie prowadziło do postępującej z jednej strony dywersyfikacji, a z drugiej decentralizacji systemu elektroenergetycznego i kreowania nowych usług, co z kolei będzie zwiększało wymagania dotyczące stabilności dostaw. Wiąże się to $\mathrm{z}$ dwukierunkowym przepływem mocy oraz problemem niestabilnego i nieprzewidywalnego charakteru produkcji energii ze źródeł odnawialnych (Biczel, 2011). Typowy profil produkcji energii elektrycznej w elektrowni słonecznej i w małej elektrowni wiatrowej charakteryzuje się dużą zmiennością w czasie, która zależy od lokalnych warunków atmosferycznych, a więc niezwykle trudno przewidzieć i zaplanować produkcję $\mathrm{z}$ takich źródeł. Obecnie trwają intensywne wysiłki na rzecz utworzenia systemów przewidujących pogodę wykorzystujących algorytmy sztucznej inteligencji. Pozwoli to na bardziej przewidywalne planowanie produkcji energii elektrycznej. W raporcie Study on the effective ... (2015, s. 28-37) przedstawiono obecne i projektowane przepływy mocy na stacji 50/10 kV usytuowanej na terenie podmiejskim w Szwecji. Warto zwrócić uwagę, że wartość przepływów ujemnych, czyli do sieci zasilającej, stanowi ok. 60-70\% wszystkich przepływów, co jest potwierdzeniem dużej zmienności tej produkcji. Zjawisko to wymaga opracowania nowych sposobów szeroko rozumianego zarządzania siecią dystrybucyjną, która sobie z taką zmiennością poradzi. Z praktyki wynika, że godzinowa zmiana popytu na energię elektryczną może być radykalnie zwiększana w zależności od różnych poziomów nasycenia zmiennymi OZE. Bez energii z OZE najwyższa zmiana popytu z godziny na godzinę wynosi ok. $9 \mathrm{GW}$, z kolei przy nasyceniu energią z OZE ponad $80 \%$ godzinowe zmiany w popycie wzrastają już do ponad $25 \mathrm{GW}$. Oznacza to wyższe wahania mocy przy wyższych poziomach zainstalowanych OZE. Jest oczywiste, że wymusza to zwiększenie wymagań w obszarze równoważenia systemu w stosunku do generacji ze źródeł konwencjonalnych (Study on the effective ..., 2015, s. 27-28). Chociaż analiza opiera się na wzorcach popytu, nasłonecznieniu i prędkościach wiatru w Niemczech, eksperci twierdzą, że można zakładać, iż w naszym kraju, ze względu na podobną szerokość geograficzną i warunki klimatyczne, przy podobnych nasyceniach OZE, wystąpią podobne zjawiska.

Lokalne zastosowanie OZE wprowadza pięć poważnych wyzwań w zakresie zarządzania tradycyjnymi i eksperymentalnymi technologiami: (1) dwukierunkowe przepływy mocy (w przypadku wysokiego nasycenia źródłami energii trzeba przewidywać przypadki nietypowego przepływu prądu, co nie występuje $\mathrm{w}$ konwencjonalnym systemie elektroenergetycznym, w którym przepływ mocy jest jednokierunkowy, tj. od zasilania do odbioru), a w przypadku dużej liczby źródeł 
może wystąpić zjawisko odwróconego przepływu mocy - w rezultacie konwencjonalne zasady koordynacji przepływu mocy przestają działać (Mumtaz, Bayram, 2016, s. 98-100); (2) wydajność zwarciowa, która w przypadku typowych przetwornic generacji rozproszonej ogranicza prąd zwarciowy maksymalnie do dwóch wartości prądu znamionowego i potrzebne jest poszukiwanie wydajniejszych rozwiązań technicznych; (3) niestabilność napięcia spowodowana lokalnymi oscylacjami, które mogą powstawać w wyniku interakcji systemu sterowania mikroźródłami, co powoduje poszukiwanie sposobów sterowania skutecznych na poziomie niskiego napięcia; (4) niska bezwładność systemu spowodowana małymi mocami źródeł wytwórczych i ich rozproszeniem, występująca szczególnie często w przypadku używania falowników, może spowodować duże odchylenia częstotliwości w trybie pracy wyspowym (zjawisko to praktycznie nie występuje w konwencjonalnym systemie elektroenergetycznym, w którym zdecydowana większość mocy jest wytwarzana przez duże generatory, które mają dużą bezwładność); (5) niepewność pracy źródeł, które są wysoce uzależnione od czynników atmosferycznych (słonce lub wiatr) i konieczność zastosowania magazynów energii.

\section{Formy organizacyjne mikrosieci i wyzwania zarządcze}

B ariery technologiczno-organizacyjne można pokonywać, organizując mikrosieci. Eksperci proponują rozwój tego komponentu rynku energetycznego w czterech kierunkach (Hirsch i in., 2018, s. 405-406; Parol, 2013, s. 26-27): (1) duże mikrosieci, obejmujące określone zbiorowości, jak kampusy, obiekty militarne, (2) średnie mikrosieci, obejmujące średniej wielkości zbiorowości, jak instytucje (szpitale, uczelnie itd.), (3) małe mikrosieci, jak obiekty biurowe, hotele, urzędy, budynki mieszkalne, (4) mikrosieci zasilające tereny odległe (patrząc od strony zasilania).

Każda z wyżej wymienionych form wymaga zastosowania nie tylko odpowiednich technologii, ale przede wszystkim metod organizatorskich i działań zarządczych. Mikrosieć jest bardzo małym systemem elektroenergetycznym. Dla takiego systemu można wydzielić trzy poziomy sterowania (Hirsch i in., 2018, s. 404): poziom I - sterowanie częstotliwością; poziom II - sterowanie napięciem, poziom III - sterowanie umożliwiające operacje ekonomiczne i optymalizacyjne dla mikrosieci, skupiające głównie zarządzanie magazynami energii, harmonogramami generacji rozproszonej oraz importem i eksportem energii elektrycznej pomiędzy mikrosiecią a systemem zasilającym. W wyżej przedstawionych zasadach sterowania brakuje m.in. działań związanych z poprawą efektywności energetycznej czy też współpracą na rzecz popularyzacji tematyki ochrony środowiska, dlatego też wydaje się niezbędne uzupełnienie zasad sterowania mikrosiecią o poziom IV - zarządzanie energią i współpraca wewnątrz mikrosieci, czyli działania w zakresie zmniejszania i równoważenia popytu i podaży energii wśród uczestników mikrosieci, edukowanie i popularyzowanie tematyki z zakresu ochrony środowiska, w tym poprawa efektywności energetycznej (Tokarčik i in., 2012, s. 47-72). Wśród pozostałych wyzwań stojących przed organizatorami mikrosieci możemy wyróżnić takie kluczowe i praktyczne aspekty, jak (Parol, 2016): ochrona przeciwporażeniowa; synchronizacja (resynchronizacja), rozumiana jako oddzielanie mikrosieci od wspólnej sieci i jej ponowne przyłączanie; możliwość pracy wyspowej w długim okresie, w zależności od potrzeb; prognozowanie krótkoterminowe wytwarzania i zapotrzebowania na moc; projektowanie i rozwój; optymalizacja pracy oraz zarządzanie efektywnością energetyczną.

\section{Procesowa koncepcja funkcjonowania mikrosieci i uwarunkowania jej wdrożenia}

$\mathbf{R}$ ozwój organizacji mikrosieci będzie wymagał dookreślenia i celowej relacji pomiędzy technologią a zarządzaniem, która zdeterminuje projektowanie odpowiedniego modelu zarządczego i implementacyjnego. Zależności pomiędzy wyborem technologii mikrosieci a procesami biznesowymi przedstawiono na rysunku 1. Przyjęte rozwiązania techniczno-organizacyjne mają także wpływ na doskonalenie technologii i współdziałających z nimi rozwiązań organizacyjnych (także o charakterze zarządczym). W tym układzie uczącym się ma szansę powstać organizacja mikrosieci zdolna do stabilnego funkcjonowania w długim czasie.

Istotną kwestią związaną $\mathrm{z}$ rozwojem mikrosieci jest identyfikacja jej operatora/agregatora, co, zdaniem niektórych autorów, jest kluczowym elementem budowy nowego segmentu mikroenergetyki prosumenckiej (Wasilewski i in., 2015, s. 45-48; Parol i in., 2016; IRENA, 2019, s. 49). W przypadku istnienia wielu rozproszonych urządzeń

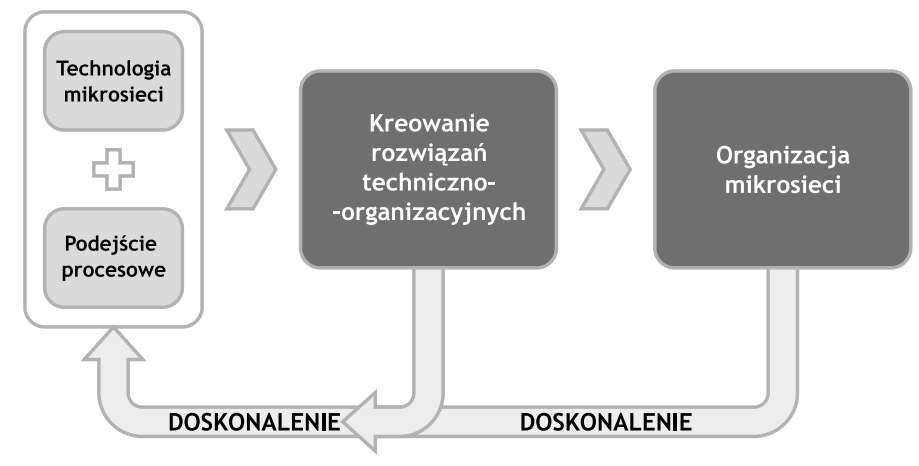

Rys. 1. Wspótzależność technologii i zarządzania dla celu organizacji mikrosieci Źródło: opracowanie własne 
do wytwarzania i magazynowania energii, w tym także prosumentów (licznych małych podmiotów), potrzebni są organizatorzy, którzy zbudują z ww. podmiotw sprawnie i elastycznie działającą całość. Właściwie zaprojektowane mikrosieci mogą wspierać działanie konwencjonalnej sieci dystrybucyjnej, zmniejszać koszty mediów z nimi związanych dla użytkowników końcowych, poprawiać bezpieczeństwo energetyczne oraz ochronę środowiska poprzez doskonalenie jakości energii, w tym wsparcie napięcia i częstotliwości, zwiększanie niezawodności dostaw energii elektrycznej, odroczenie potrzeb rozbudowy sieci oraz związanych z tym nakładów, lepszą zdolność przywracania zasilania po awarii sieci dystrybucyjnej (lub mniejszą wrażliwość na awarie w sieci zasilającej), budowę lokalnych źródeł zaopatrzenia w energię cieplną i ciepłej wody użytkowej opartych na OZE, mniejszą emisję oznaczającą poprawę warunków zdrowotnych dla mieszkańców poprzez wykorzystanie odnawialnych źródeł energii, a w konsekwencji poprawę efektywności energetycznej. Zatem podstawową kwestią dla powodzenia inicjatywy mikrosieci jest potrzeba stworzenia odpowiedniego modelu segmentu mikroenergetyki prosumenckiej, który z jednej strony zapewni opłacalność w sensie ekonomicznym tej inicjatywy, z drugiej przygotuje organizację mikrosieci. O ile w przypadku kwestii ekonomicznych można mówić o istnieniu gotowych narzędzi, jak na przykład model DER-CAM (ang. Distributed Energy Resources Customer Adoption Model) czy też inne modele przydatne do integracji zmiennych źródeł odnawialnych energii, o tyle w przypadku aspektów organizacyjnych, przez które rozumie się przygotowanie procesów przyszłej organizacji obejmującej różne aspekty jej działalności, a następnie wdrożenie i zarządzanie nimi - można stwierdzić brak opracowań w tym zakresie. Istniejące publikacje opisują potrzebę identyfikacji tych procesów (CEER, 2019, s. 21-23).

Koncepcja procesowa mikrosieci bazuje na założeniu, że może ona pełnić rolę sterowalnego odbioru i sterowalnego wytwarzania. W przypadku sterowalnego odbioru można zastosować mechanizm DSR (ang. Demand Side Response), który pozwala operatorowi sieci dystrybucyjnej (dzisiaj $\mathrm{OSP}^{4}$ ) zarządzać nią poprzez zmniejszenie zapotrzebowania na energię elektryczną w określonym czasie na określonym obszarze i w ten sposób stabilizować pracę sieci. Kontrolowana regulacja obciążenia sieci może mieć pozytywny wpływ na zmniejszenie potrzeb inwestycyjnych właściciela sieci. Właściwe zarządzanie sterowalnymi odbiorami i wytwarzaniem pozwala myśleć o mikrosieci jako o jednostce gospodarczej o charakterze dochodowym. Ciekawym przykładem współpracy OSD - uczestnicy rynku może być wykorzystanie technologii ładowania/rozładowania samochodów elektrycznych, co dobrze opisano w CEER (2019, s. 23-24). Obecnie wskazuje się na potrzebę ściślejszej współpracy pomiędzy operatorami w celu ułatwienia wdrażania nowych inicjatyw związanych z OZE (TSO - DSO Report, 2019, s. 4).

Implementację procesowej organizacji mikrosieci proponuje się podzielić na następujące etapy: (1) działania inicjujące - określenie modelu mikrosieci oraz jej lidera/operatora, w tym jej mix energetyczny obejmujący zapotrzebowanie na moc i energię elektryczną i cieplną; (2) przyłączenie do sieci dystrybucyjnej OSD (on grid), który w razie potrzeby zapewniłby potrzebne rezerwy mocy - wybrane elementy mikrosieci byłyby sterowane poprzez sterowniki lokalne oraz koordynowane przez centralny sterownik mikrosieci Ze względu na słabe kompetencje w bilansowaniu popytu i podaży mocy odłączenie takiego mikrosystemu od OSD znacznie pogorszyłoby parametry jakościowe energii. Przepływy na granicach mikrosieć - OSD byłyby częste i duże. OSD długoterminowo mogłoby korzystać z możliwości, jakie daje mikrosieć dla swoich potrzeb; (3) przyłączenie do sieci dystrybucyjnej OSD (on grid), w którym odłączenie od sieci OSD nie pogorszy wskaźników jakościowych energii elektrycznej, a może ją polepszyć ze względu na możliwość podtrzymania zasilania z własnych źródeł w przypadku zakłóceń w dostawach z sieci OSD. Wybrane elementy mikrosieci byłyby sterowane poprzez sterowniki lokalne oraz koordynowane przez centralny sterownik mikrosieci. Przepływy na granicach mikrosieć - OSD byłyby rzadkie i niewielkie. Współpraca z OSD ograniczałaby się jedynie do pokrywania rzadkich niedoborów produkcji (sytuacje nadzwyczajne) i przyjmowania nadmiarowych porcji wytworzonej energii elektrycznej. Mikrosieć realizowałaby operacje ekonomiczne i optymalizacyjne dla swoich potrzeb, skupiając się głównie na zarządzaniu magazynami energii, harmonogramami generacji rozproszonej oraz importem i eksportem energii elektrycznej pomiędzy mikrosiecią a systemem zasilającym. OSD długoterminowo mogłoby korzystać z możliwości, jakie daje mikrosieć dla swoich potrzeb; (4) praca jako system w pełni autonomiczny - wyspowy (off grid), odłączony od sieci dystrybucyjnej OSD, w którym właściwy dobór infrastruktury i zarządzanie gwarantowałby zasilanie odbiorów z posiadanych źródeł oraz skutecznie bilansował swój obszar. Wybrane elementy mikrosieci byłyby sterowane poprzez sterowniki lokalne oraz koordynowane przez centralny sterownik mikrosieci. Mikrosieć realizowałaby operacje ekonomiczne i optymalizacyjne dla swoich potrzeb, skupiając się na zarządzaniu magazynami energii, harmonogramami generacji rozproszonej oraz importem i eksportem energii elektrycznej pomiędzy mikrosiecią a systemem zasilającym. OSD czasowo mógłby korzystać z możliwości, jakie daje mikrosieć dla swoich potrzeb.

Założenie, że od razu można zbudować mikrosieć autonomiczną, jest zdaniem autorów zbyt optymistyczne i ryzykowne. Barierą są także aktualne uwarunkowania techniczno-ekonomiczne oraz organizacyjne i prawne funkcjonowania krajowego systemu elektroenergetycznego. Powyższe założenia uwzględniające pewne rozłożenie w czasie budowy mikrosieci daje $\mathrm{z}$ jednej strony operatorowi mikrosieci czas potrzebny na wdrożenie i utrwalenie procesów związanych z obsługą mikrosieci, z drugiej daje szansę OSD/OSP na przygotowanie się do prowadzenia ruchu sieci na danym terenie $\mathrm{z}$ istniejącą infrastrukturą mikrosieci.

\section{Identyfikacja kluczowych procesów w organizacji mikrosieci - wkład do nauki i praktyki zarządzania}

W ychodząc od wypracowanej, procesowej koncepcji organizacji mikrosieci, a następnie przyjmując tradycyjny podział w literaturze przedmiotu procesów 
przedsiębiorstwa uzupełniony o wyniki wywiadów z ekspertami i użytkownikami technologii OZE, pogrupowano procesy $\mathrm{w}$ organizacji mikrosieci na: podstawowe, pomocnicze i zarządcze. Zasadniczym kryterium merytorycznym wyróżnienia procesów jest zapewnienie organizacji mikrosieci sterowalnej ciągłości działania. Jest to taka cecha procesów, która zapewnia na linii źródło energii - odbiór -magazynowanie -dystrybucja -odbiorca, sterowany przez Operatora, stabilny rozpływ mocy, także w przypadku dużej liczby źródeł zasilania usytuowanych w pobliżu punktów odbiorów oraz skoordynowaną pracę wyspową różnych źródeł energii (wiatr, słońce) i urządzeń odbiorczych. Identyfikacja, opisanie i analiza procesów umożliwi rozwój architektury procesowej oraz ich automatyzację i algorytmizację (Zieliński, 2017, s. 92-94). Należy wskazać, zgodnie z podejściem systemowym, na potrzebę prawidłowej implementacji i zarządzania wszystkimi niżej wymienionymi procesami i ich relacjami. Zawsze trzeba analizować wpływ zmian w jednym procesie na inne $\mathrm{z}$ nim powiązane. Zaproponowana lista procesów wraz $\mathrm{z}$ ich zakresem merytorycznym jest zestawieniem otwartym - intencją autorów jest otwarcie dyskusji.

Wyróżniono osiem procesów umożliwiających organizację i zarządzanie mikrosiecią:

- podstawowe:

1. Przyłączanie nowych źródeł/odbiorów, którego celem jest takie przyłączanie nowych lub zmiana mocy dla istniejących podmiotów mikrosieci, aby zapewnić długoteminowe równoważenie podaży i popytu.

2. Planowanie rozwoju, którego celem może być takie kierowanie rozwojem, aby minimalizować wpływ nowych elementów mikrosieci na sieć elektroenergetyczną, do której są przyłączone (brak potrzeby rozbudowy sieci).

3. Projektowanie, którego celem będzie przewidywanie wpływu nowych elementów na pracę istniejących w sposób zapewniający bezpieczeństwo użytkowników mikrosieci.

4. Prowadzenie ruchu i zarządzanie mocą w mikrosieci, którego celem jest nadzór nad pracą sieci, w której występuje możliwość podtrzymania zasilania lokalnie przy braku dostaw (planowe - awaryjne) z sieci OSD oraz przepływy dwukierunkowe mocy.

5. Współpraca $z$ podmiotami rynku energii, w tym z OSD, którego celem jest opracowanie i stałe doskonalenia odpowiedniego sposobu rozliczeń za nowe usługi.

- pomocnicze:

1. Eksploatacja / utrzymanie, które musi uwzględniać fakt, że do sieci są przyłączone źródła energii, które muszą pracować zgodnie z grafikami pracy, co bardzo ogranicza np. planowe wyłączenia sieci i preferuje rozwój prac pod napięciem.

2. Zarządzanie zasobami ludzkimi, którego celem jest właściwy dobór osób do obsługi infrastruktury mikrosieci, jej sterowania oraz współpracy w podmiotami zewnętrznymi.

- zarządcze:

1. Efektywne zarządzanie energią, którego celem jest stworzenie mechanizmów efektywnościowych, ukierunkowanych na zaspokajanie potrzeb energetycznych uczestników mikrosieci za pomocą coraz mniejszej ilości energii pochodzącej ze źródeł odnawialnych. Mechanizmy te będą sterować ww. procesami mikrosieci.

\section{Podsumowanie}

$\mathbf{Z}$ aprezentowana procesowa koncepcja mikrosieci umożliwiła wyodrębnienie i zaprojektowanie procesów związanych z tworzeniem i utrzymaniem nowej formy organizacyjnej rynku energetycznego. Rozwój OZE i towarzyszących mu technologii jest szansą na bezpieczną dywersyfikację źródeł energii przy założeniu prawidłowego zaimplementowania technologii w procesach organizacyjnych i vice versa. Zidentyfikowanie i ustandaryzowanie procesów organizacyjnych ułatwi rozwój architektury procesowej wraz z automatyzacją i algorytmizacją procesów organizacji mikrosieci.

Aktualnie pilne są dwa wyzwania badawcze i aplikacyjne: (1) opracowanie mechanizmu zarządzania energią i mocą w mikrosieci, który będzie obejmował: infrastrukturę pomiarową, metody regulacji produkcji i zużycia energii oraz zarządzanie mocą; (2) stworzenie mechanizmów efektywnościowych, czyli zaspokajanie jej potrzeb energetycznych za pomocą coraz mniejszej ilości energii pochodzącej oczywiście ze źródeł odnawialnych. Stąd wynika potrzeba realizacji rozwiązań pilotażowych testujących różne rozwiązania technologiczne, organizacyjne, ekonomiczne i regulacyjne mikrosieci. Projektowanie procesów równolegle $\mathrm{z}$ implementowaniem technologii pozwoli uniknąć wielu problemów na etapie wdrożenia i utrzymania mikrosieci.

Ranga zagadnienia mikrosieci wpisuje się w strategię bezpieczeństwa energetycznego Polski, które jest silnie zależne od dywersyfikacji dostaw paliw: węgla, ropy naftowej i gazu ziemnego. W przypadku węgla można mówić o jego własnych, długoterminowych, dużych zapasach. W przypadku ropy naftowej obok dostaw z Rosji rurociągiem Przyjaźń, Polska dysponuje naftoportem w Gdańsku. Jeśli chodzi o gaz ziemny to PGNiG planuje doprowadzenie do sytuacji, w której $1 / 3$ gazu będzie pochodzić $\mathrm{z}$ wydobycia krajowego, 1/3 będzie importowana ze Wschodu, a 1/3 będzie importowana ze Skandynawii do terminala LNG w Świnoujściu. Mikrosieci mogą być kolejnym elementem dywersyfikacji dostaw energii, zastępując w jakiejś części paliwa kopalne.

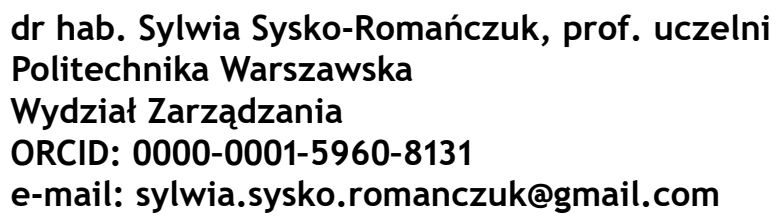




\section{Przypisy}

1) Obecnie praca wyspowa jednostek wytwórczych jest możliwa jedynie na wyspę urządzeń tego wytwórcy po skutecznym odłączeniu od pozostałej części wspólnej sieci, jeżeli uwzględniono to $\mathrm{w}$ warunkach przyłączenia. Jeżeli nie, to $\mathrm{w}$ momencie wystąpienia zakłócenia w sieci OSD urządzenia wytwórcze muszą się wyłączyć samoczynnie, co oznacza, że w wielu przypadkach jednostki wytwórcze mające możliwość pracy na wyspę, nie wykorzystują tych możliwości.

2) IRiESD - Instrukcja Ruchu i Eksploatacji Sieci Dystrybucyjnej, czyli kluczowy dokument regulujący zasady współpracy OSD z innymi podmiotami przyłączonymi lub chcącymi się przyłączyć do wspólnej sieci będącej własnością OSD.

3) Analizując literaturę przedmiotu, można dojść do wniosku, że na dzień dzisiejszy można używać tych pojęć zamiennie. W różnych pozycjach literaturowych używa się terminów mikrosieć lub minisieć w odniesieniu do tej samej materii opisanej w niniejszej publikacji.

4) Funkcjonowanie sieci dystrybucyjnej poprzez istnienie rozproszonych OZE i agregujących je mikrosieci skomplikuje się, co będzie wymagało od OSD dodatkowych aktywności i kompetencji zastrzeżonych obecnie dla OSP (Operatora Systemu Przemysłowego).

\section{Bibliografia}

[1] Biczel P. (2011), Wytwarzanie energii w mikrosieciach, „Automatyka-Elektryka-Zakłócenia”, Nr 4, s. 76-83.

[2] CEER (2019), New Services and DSO Involvemen, Council of European Energy Regulators a Conclusions Paper, ref. C18DS-46-08, Brussels, Belgium.

[3] Hildermeier J., Kolokathis Ch., Rosenov J., Hogan M., Wiese C., Jahn A. (2019), Start with Smart: Promising Practices for Integrating Electric Vehicles into the Grid, https://www.raponline.org/ knowledge-center/start-with-smart-promising-practicesintegrating-electric-vehicles-grid/, access date: 22.04.2019.

[4] Hirsch A., Yael Parag Y., Guerrero J. (2018), Microgrids: A Review of Technologies, Key Drivers, and Outstanding Issues, „Renewable and Sustainable Energy Reviews", Vol. 90, pp. 402-411.

[5] IRENA (2019), Innovation Landscape for a Renewable-powered Future: Solutions to Integrate Variable Renewables, https://www. irena.org/publications, access date: 22.02.2019.

[6] Kłysz M. (1999), Rynek energii elektrycznej w Polsce, „Przegląd Organizacji”, Nr 6, s. 16-20.

[7] Krysta B., Michalski D., Lot G. (2002), Wplyw otwarcia rynku energii elektrycznej na koncepcje działalności jego uczestników, „Przegląd Organizacji”, Nr 11, s. 21-26.

[8] Mumtaz F., Bayram I.S. (2016), Planning, Operation, and Protection of Microgrids: An Overview, 3rd International Conference on Energy and Environment Research, Energy Procedia, Barcelona, pp. 94-100.

[9] Parol M. (2016), Mikrosieci - przyszłosciowe struktury sieci dystrybucyjnych, „Przegląd Elektrotechniczny”, Nr 8, s. 1-5.

[10] Parol M. (red.), (2013), Mikrosieci niskiego napięcia, Oficyna Wydawnicza Politechniki Warszawskiej, Warszawa.

[11] Parol M., Rokicki Ł., Połecki M., Parol R., Komarnicki P., Arendarski B. (2016), Projektowanie i optymalne sterowanie praca mikrosieci niskiego napięcia na obszarach wiejskich, Energetyka Prosumencka w Wymiarach Zrównoważonego Rozwoju,
III Interdyscyplinarna Konferencja Środowisk Naukowych. Koszęcin, s. 1-20.

[12] Pylak K., Bojar E., Bojar M. (2017), Możliwości tworzenia klastrów energii w Polsce, „Przegląd Organizacji”, Nr 9, s. 22-27.

[13] Ryan H., Ghonima M., Kleissl J., Tynan G., Victor D.G. (2017), Evaluating Business Models for Microdgrids: Interactions of Technology, „Energy Policy”, Vol. 103, pp. 47-61.

[14] Study on the Effective Integration of Distributed Energy Resources for Providing Flexibility to the Electricity System (2015), https://ec.europa.eu/energy/en/studies/study-effective-integration-distributed-energy-resources-providing-flexibilityelectricity, access date: 22.03.2019.

[15] Tokarčik A., Rovňák M., Lechwar M., Wisz G. (2012), Zarzadzanie energia $w$ jednostkach samorzadu terytorialnego. Wyd. CeDeWu Sp. z o.o., Warszawa.

[16] TSO - DSO Report (2019), An Integrated Approach to Active System Management, https://docstore.entsoe.eu/Documents/ Publications/Position\%20papers\%20and\%20reports/TSODSO_ASM_2019_190416.pdf, access date: 22.03.2019.

[17] Wasiak I., Pawełek R., Kelm P. (2013), Praca autonomiczna mikrosystemów elektroenergetycznych niskiego napięcia, Zeszyty Naukowe Wydziału Elektrotechniki i Automatyki, Nr 33, s. 87-90.

[18] Wasilewski J., Kaleta M., Baczyński D. (2015), Wybrane zagadnienia rozwoju mikrosieci energetycznych $w$ Polsce, „Polityka Energetyczna”, Tom 18, Zeszyt 1, s. 45-48.

[19] Zieliński J.S. (2017), Transactive Energy and Internet of Everything, „Rynek Energii”, Nr 2, s. 92-94.

\section{Micro-grids as an Innovative Component of the Energy Market Diversification in Poland}

\section{Summary}

Currently, most of the electricity is generated in large conventional power plants connected to the transmission grid. The existing power infrastructure is adapted to the abovementioned conditions. Driven by the connection of an increasing number of variable renewable energy sources (RES), a new approach to the organisation of the electricity market is necessary, including the design and operation of the power systems, which implies the need to seek for new ways of supply and demand balancing. The scientific goal of the paper is to identify key processes in the organisation of a micro-grid based on its process concept. Eight processes enabling the organisation and management of microstructure were distinguished: (1) basic ones: connecting new sources / receipts, development planning, design, operation and power management in a microchip, cooperation with energy market entities, including OSD; (2) auxiliary ones: operation / maintenance, human resource management; (3) management ones: effective energy management. Introduction of micro-grids to the energy market will require the development of a new way of broadly understood distribution network management.

\section{Keywords}

microgrids, management, processes, energy market 